DOI: https://doi.org/10.24867/07NU05Resimic

\title{
ULOGA DRUŠTVENIH MREŽA U PRIPRAVNOSTI I ODGOVORU ZAJEDNICE NA KATASTOFALNE DOGAĐAJE
}

\section{THE ROLE OF SOCIAL NETWORKS IN PREPAREDNESS AND RESPONSE TO DISASTERS}

\author{
Nikola B. Resimić, Fakultet tehničkih nauka, Novi Sad
}

\section{Oblast - UPRAVLJANJE RIZIKOM OD KATASTROFALNIH DOGAĐAJA I POŽARA}

Kratak sadržaj - Ovaj rad razmatra ulogu društvenih mreža u efikasnoj komunikaciji tokom vanrednih situacija. Analizirani su različiti alati društvenih medija kako bi se otkrilo kako se mogu koristiti za bolju komunikaciju sa javnošću u vanrednim situacijama i kako poboljšati spremnost $i$ odgovor na katastrofe, te smanjiti broj žrtava i štete.

Ključne reči: Društvene mreže, vanredne situacije, upravljanje rizikom od katastrofalnih događaja, spremnost, reagovanje $u$ vanrednim situacijama, krizna komunikacija

Abstract - This paper reviews the role of social networks in effective communication during an emergency. Different social media tools will be analized in order to find out how can they be utilized to provide better communication with the public in emergencies and how to enhance preparedness and response to disaster, reduce casualties and damages.

Keywords: Social networks, emergency situations, disaster risk management, disaster preparedness, disaster response, crisis communication

\section{UVOD}

Nastupanje bilo koje krize izaziva pojavu i razmenu velikog broja informacija u celokupnom okruženju. Za efikasno upravljanje krizom neophodna je saradnja na svim nivoima, brzo donošenje odluka i i usklađena komunikacijska interakcija svih aktera. Upravljanje informacijama pre, $\mathrm{u}$ toku i nakon katastrofalnog događaja može imati direktan uticaj na upravljanje krizom.

Tokom proteklih decenija društvene mreže se sve više prepoznaju kao značajan alat u pripravnosti društva za katastrofalne događaje i upravljanje u vanrednim situacijama. Kako priprema $\mathrm{i}$ reagovanje u kriznim situacijama zahteva pravovremeno raspolaganje relevantnim informacijama i koordinaciju aktivnosti svih zainteresovanih strana - od nadležnih za reagovanje pa do svakog pojedinca u zajednici, upotreba društvenih mreža u uslovima vanrednih situacija omogućava širenje važnih informacija među pojedincima i zajednicama,

\section{NAPOMENA:}

Ovaj rad proistekao je iz master rada čiji mentor je bio dr Mladen Pečujlija, vanr. prof. kao i prijem ažuriranih podataka od strane onih koji prvi reaguju [1]. Povećanje broja korisnika društvenih mreža nije bio jedini faktor koji je tome doprineo, već i prepoznavanje različitih prednosti njihove upotrebe $u$ takvim situacijama. Na primer, u upravljanju rizicima od katastrofalnih događaja, društvene mreže (Facebook, Instagram, Twitter...) mogu se koristiti na različite načine: upozorenja, širenje vesti o žrtvama i šteti, objavljivanje multimedijalnih informacija kao što su video snimci $\mathrm{i}$ fotografije, praćenje javne rasprave, upravljanje kriznom situacijom i širenje informacija o odgovoru na aktuelni događaj, stvaranje socijalne kohezije i podsticanje donacija [2].

Predmet ovoga rada je ispitivanje uloge društvenih medija $\mathrm{u}$ upravljanju katastrofalnim događajima od strane državnih organa i službi i njihova upotreba od strane građana. Cilj rada je utvrđivanje načina na koji aplikacije na društvenim medijima mogu uticati na upravljanje katastrofalnim događajima i koje su njihove prednosti i nedostaci u odnosu na tradicionalne medije. Takođe, cilj rada je $\mathrm{i}$ da istraži iskustva o informisanju građana putem društvenih mreža u vreme vanrednih situacija i da utvrdi nivo poverenja u društvene mreže u Srbiji.

\section{UPOTREBA DRUŠTVENIH MREŽA TOKOM KATASTROFALNIH DOGAĐAJA}

Tokom katastrofalnih događaja društvene mreže omogućavaju pristup relevantnim i pravovremenim informacijama koje su neophodne nadležnima službama za reagovanje u takvim situacijama. Između ostalog, te informacije obuhvataju podatke o pogođenim područjima, obimu pretrpljene štete, broju i lokaciji ugroženog stanovništva. Primetno je da dolazi do povećanog korišćenja društvenih mreža tokom vanrednih situacija širom sveta.

Tokom zemljotresa na Haitiju 2010. godine izazvane su katastrofalne materijalne štete i smrt stotina hiljada ljudi. Ubrzo nakon zemljotresa, ogroman broj stanovnika ostao je zarobljen u ruševinama, a već ranjiva infrastruktura $u$ zemlji je potpuno razorena. Dok su timovi stranih spasilačkih jedinica pokušavali da dospeju do žrtava, humanitarne agencije borile su se da zadovolje osnovne potrebe kao što su hrana, voda, sklonište i medicinska nega za pogođena lica [3]. Twitter je odigrao posebno veliku ulogu u širenju informacija jer se brzo ispunjavao vestima o zemljotresu i načinima pružanja pomoći. Haiti je postao jedna od glavnih tema, obaveštenja o mogućim 
lokacijama ugroženih sve više su se prenosila putem društvenih medija (npr. rodbina žrtava koja je slala informacije direktno agencijama nadležnim za spašavanje stanovništva) ili putem SMS poruka [4], a veliki broj tvitova pozivao je na donacije $u$ novcu ili robnim zalihama za pogođenu državu.

Nakon zemljotresa u Japanu 2011. godine uprkos predviđanju velikih cunamija, lokalna vlada nije mogla da izda upozorenje o cunamiju na početnoj stranici lokalnih samouprava zato što su serveri računara bili isključeni zbog nestanka električne energije nakon zemljotresa. Umesto toga uspeli su da kreiraju nalog na Twitter-u i Facebook-u koristeći svoje privatne mobilne telefone i da pošalju informacije putem ovih društvenih mreža [5]. Nakon katastrofalnog događaja prvi tvit objavljen je u roku od deset minuta [5].

Online blogovi i društvene mreže odigrali su bitnu ulogu $\mathrm{u}$ olakšavanju razmene i razumevanja informacija nakon oštećenja nuklearne elektrane u Fukušimi izazvane usled dejstva zemljotresa i udara cunamija. Građani su aktivno učestvovali u blogovima i na Facebook-u, Twitter-u i YouTube-u, razmenjujući informacije i upućujući druge na važne novinske članke ili video snimke, a posebno na nivo nuklearnog zračenja.

Tokom uragana Sendi koji je pogodio područje Kariba i Severne Amerike u oktobru 2012. godine javnost, vladine agencije i organizacije za reagovanje sada se više okreću društvenim mrežama nego ikad pre, kao ključnom kanalu komunikacije. Kancelarija za upravljanje vanrednim situacijama u Njujorku davala je ažurirane informacije i naloge za evakuaciju na svakih sat vremena putem svog Twitter naloga. Američka Federalna agencija za upravljanje kriznim situacijama (FEMA), takođe je koristila društvene medije za razmenu informacija $\mathrm{i}$ napravila specijalne stranice o uraganu Sendi na Twitter i Facebook profilima.

Tokom velikih poplava i bujica koje su pogodile Srbiju, Hrvatsku i Bosnu i Hercegovinu u maju 2014. godine društvene mreže služile su kao kanal za brzo razmenjivanje informacija i imale su veoma bitnu ulogu u olakšavanju evakuacije i spašavanja . Haštagovi koji su obeležili ovaj period su: \#poplave, \#SerbiaFloods i \#Srbija.

\section{METODOLOGIJA ISTRAŽIVANJA}

Predmet ovog kvantitativnog istraživanja je ispitivanje stavova ispitanika o ulozi društvenih mreža u pripravnosti i odgovoru zajednice na katastrofalne događaje i utvrđivanje nivoa poverenja u upotrebu društvenih mreža tokom takvih događaja.

Istraživanje je izvršeno putem online upitnika koji je distribuiran putem e-maila i društvene mreže Facebook. U prvoj fazi istraživanje je sprovedeno među studentima univerziteta uključenih $u$ K-FORCE Projekat i to Fakulteta tehničkih nauka u Novom Sadu, Rudarskogeološko-građevinskog fakulteta u Tuzli i Arhitektonskograđevinsko-geodetskog fakulteta u Banjaluci.

Više od polovine odgovora ispitanika dobijeno od strane studenata navedenih fakulteta.
Upitnik se sastoji od 16 pitanja zatvorenog tipa. Kroz pitanja ispitanici su mogli da izaberu neke od unapred ponuđenih odgovora ili da davanjem ocene od 1 do 5 izraze svoje slaganje ili neslaganje sa navedenim stavovima.

Za popunjavanje upitnika korišćena je online platforma Google upitnici. Ovakav način sprovođenja istraživanja omogućava brzo i efikasno popunjavanje upitnika, odgovori se automatski prikupljaju i rezultati su prikazani procentualno putem grafikona.

Poredeći karakteristike samog uzorka, može se zaključiti da su žene ispitanici iskazale veću spremnost na učešće u istraživanju $(63,2 \%)$ nego muškarci $(36,8 \%)$. Kada je u pitanju starost ispitanika, uzorak najvećim delom obuhvata ispitanike u dobi od 25-34 godine $(47,4 \%)$ i 18 24 godine $(30,7 \%)$, što je sasvim očekivano zbog učešća studentske populacije. U skladu sa tim najveći broj ispitanika je visoko obrazovan, od toga $64 \%$ ispitanika ima diplomu osnovnih akademskih studija, a 15,8\% diplomu magistra.

\section{REZULTATI ISTRAŽIVANJA}

Nakon sprovedenog istraživanja upotrebom deskriptivne statističke analize opisani su prikupljeni odgovori. Svi ispitanici (100\%) naveli su da imaju nalog na nekoj od društvenih mreža, a što se tiče društvenih mreže na kojima imaju naloge najveći broj ispitanika je naveo Facebook $(94,7 \%)$, Instagram $(58,4 \%)$ i nalog na YouTube kanalu (28,3\%) (Grafikon 1). Čak 90,4\% ispitanika izjasnilo se da društvenim mrežama najčešće pristupa putem mobilnog telefona, dok u tu svrhu desktop ili laptop računar upotrebljava $9,6 \%$ ispitanika.

Na kojoj od društvenih mreža ili servisa za deljenje sadržaja imate otvoren nalog?

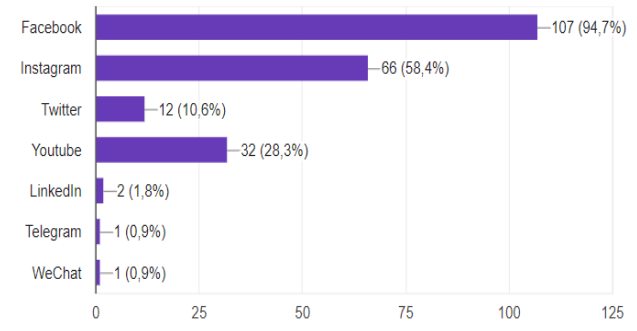

\section{Grafikon 1 - Procentualna zastupljenost upotrebe različitih društvenih mreža}

$\mathrm{Na}$ pitanje „Koliko često pristupate društvenim mrežama?“", 80,7\% ispitanika odgovorilo je da to čini nekoliko puta dnevno, 13,2\% jednom dnevno, 1,8\% nekoliko puta sedmično, dok $4,4 \%$ ispitanika to čini nekoliko puta u toku meseca.

Polovine od ukupnog broja ispitanika (50\%) odgovorilo je da su nekada koristilili društvene mreže u svrhu obaveštavanja o katastrofalnim događajima i vanrednim situacijama (npr. olujno nevreme, obilne padavine, zemljotresi...), 34,2\% ispitanika nije koristilo, a 15,8\% ispitanika nije sigurno da li su ikada upotrebili društvene mreže u tu svrhu. Da bi pokušali da provere vest vezanu 
za neku vanrednu situaciju (npr. objavljenu putem televizije ili radio programa) na zvaničnim nalozima državnih službi na društvenim mrežama izjasnilo se $56,1 \%$ ispitanika, $21,1 \%$ ispitanika nije sigurno, dok $22,8 \%$ ne bi to uradilo.

Na pitanje da li znaju da Sektor za vanredne situacijeMUP Srbije ima svoje zvanične naloge na društvenim mrežama (Facebook nalog i Youtube kanal) 27,2\% ispitanika odgovorilo je da, a 72,8\% ne (Grafikon 2). Uočljiva je velika razlika u procentima o saznanju da određene državne službe imaju svoje zvanične naloge na društvenim mrežama.

Ipak, 71,9\% ispitanika odgovorilo je da bi u budućnosti pratili naloge državnih službi u svrhu obaveštavanja o aktuelnim događajima, dok 20,2\% nije sigurno, a 7,9\% ispitanika se izjasnilo da ne bi pratili te naloge.

Da li znate da Sektor za vanredne situacije-MUP Srbije ima svoje zvanične naloge na društvenim mrežama (Facebook nalog i Youtube kanal)?

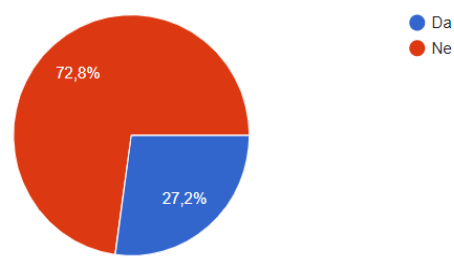

Grafikon 2 - Da li znate da Sektor za vanredne situacijeMUP Srbije ima svoje zvanične naloge na društvenim mrežama (Facebook nalog $i$ Youtube kanal)?

Najveći broj ispitanika $(70,2 \%)$ navelo je da bi zatražili pomoć putem društvenih mreža (Grafikon 3) u toku vanredne situacije ukoliko bi bili u mogućnosti da to urade, međutim samo $13,2 \%$ ih veruje da bi državne službe hitno odgovorile na taj poziv, $44,7 \%$ ispitanika nije sigurno u to, a $42,1 \%$ ne očekuje hitan odgovor nadležnih državnih službi na takav poziv.

Da li biste zatražili pomoć putem društvenih mreža u toku vanredne situacije ukoliko biste bili u mogućnosti da to uradite?

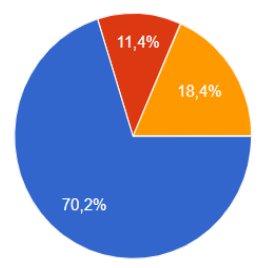

Da

Nisam siguran

\section{Grafikon 3 - Procentualni prikaz spremnosti ispitanika da zatraže pomoć putem društvenih mreža tokom vanredne situacije}

Što se tiče upotrebe društvenih mreža u toku vanrednih situacija u budućnosti, 75,4\% ispitanika očekuje da će ona biti povećana, $19,3 \%$ nije sigurno, a 5,3\% ispitanika ne očekuje povećanje upotrebe društvenih mreža u toku vanrednih situacija u budućnosti (Grafikon 4).
Da li očekujete da će upotreba društvenih mreža u toku vanrednih situacija u budućnosti biti povećana?

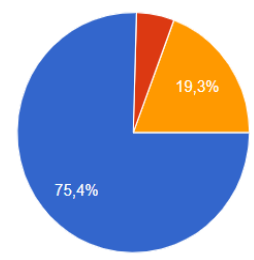

$\mathrm{Da}$

Nisam siguran

\section{Grafikon 4-Da li očekujete da će upotreba društvenih mreža u toku vanrednih situacija u budućnosti biti povećana?}

Kao najveći nedostatak prilikom korišćenja društvenih mreža u vanrednim situacijama $57,9 \%$ ispitanika ističe mogućnost širenja netačnih informacija, 21,9\% veruje da društvene mreže možda neće funkcionisati $u$ toku vanredne situacije, a 20,2\% ispitanika misli da društvene mreže nisu pouzdan izvor informacija (Grafikon 5).

Prema Vašem mišljenju najveći nedostatak prilikom korišćenja društvenih mreža u vanrednim situacijama je?
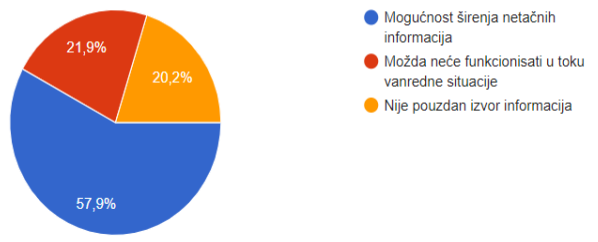

Grafikon 15 - Prikaz mišljenja ispitanika o najvećim nedostacima društvenih mreža prilikom njihove upotrebe $u$ vanrednim situacijama

\section{ZAKLJUČAK}

Uloga društvenih mreža u pripravnosti i odgovoru zajednice na katastrofalne događaje je poslednjih godina izuzetno dobila na značaju. Tome je posebno doprineo porast upotrebe pametnih telefona sa instaliranim aplikacijama kao što su Facebook, Twitter, Instragram i slične koje omogućavaju svojim korisnicima deljenje informacija $u$ vidu teksta, fotografija, audio i video zapisa. Društvene mreže imaju potencijal da utiču na način na koji pojedinci misle, ponašaju se i odgovaraju na informacije $\mathrm{i}$ situacije uopšte $\mathrm{u}$ vreme katastrofalnih događaja.

Tradicionalni mediji, poput televizije, štampe i radija, omogućavaju informisanje građana, ali ne dozvoljavaju povratne informacije. Suprotno tome, društvene mreže dozvoljavaju distribuciju informacija i odgovor od građana. Time društvene mreže, kao alat za komunikaciju u uslovima vanrednih situacija i katastrofalnih događaja, mogu bite korišćene od strane nadležnih službi za reagovanje sa ciljem informisanja građana i koordinacije aktivnosti sa jedne strane, dok sa druge strane omogućavaju aktivno učešće javnosti putem širenja informacija. Upravo taj kvalitet društvene mreže čini neprocenjivim alatom. 
$\mathrm{Na}$ osnovu rezultata istraživanja potvrđeno je da se društvene mreže koriste svakodnevno i u velikom obimu, pa stoga mogu biti upotrebljene u svrhu podizanja svesti građana o opasnostima koje ih okružuju, kao i za edukaciju o preventivnim merama u cilju povećanja pripremljenosti i odgovora na određeni događaj. Pored preventivnih aktivnosti, mogu biti od pomoći i prilikom reagovanja i otklanjanja posledica događaja koji su se dogodili. Građani koje se zateknu na ugroženom području mogu fotografisati ili snimiti veliki broj detalja kojim će informisati nadležne službe i druge građane o situacii na terenu i koji mogu biti važni za donošenje odluka o delovanju pripadnika službi zaštite i spasavanja. Takođe, društvene mreže mogu imati veoma bitnu ulogu u organizovanju zajedničkih akcija građana, podsticanju volontiranja i donacija.

Uočeno je, međutim, da veliki procenat ispitanika nije upoznat sa činjenicom da državne službe za reagovanje u kriznim situacijama imaju svoje naloge na društvenim mrežama i da postoji nepoverenje u upotrebu društvenih mreža zbog mogućnosti njihove zloupotrebe i tehničkih nedostatatak. Ipak, evidentno je da postoji svest o tome da društvene mreže predstavljaju alat koji omogućava brzo širenje informacija i slanje upozorenja.

Da bi se društvene mreže što efikasnije koristile $u$ podizanju pripravnosti i odgovoru društva na katastrofalne događaje, neophodno je da svi relevantni subjekti budu informisani o mogućnostima njihovog korišćenja pre, tokom i nakon takvih događaja. Samo na taj način biće moguće iskoristiti sve prednosti korišćenja društvenih mreža.

\section{LITERATURA}

[1] Šekarić Nevena, Kešetović Želimir. 2018. Uloga društvenih mreža u upravljanju vanrednim situacijama. Originalni naučni rad, Fakultet bezbednosti, Univerzitet u Beogradu, Beograd
[2] Imran Muhammad, Elbassuoni Shady, Castillo Carlos, Diaz Fernando, Meier Patrick. 2013. Extracting information nuggets from disaster-related messages in social media. Paper presented at the ISCRAM Conference - Baden-Baden, Germany, May 2013

[3] Hagar Christine. 2012. Crisis Information Management-Communication and Technologies. Chandos Publishing, Oxford, UK

[4] Dugdale Julie, Van de Walle Bartel, Koeppinghoff Corinna. 2012. Social Media and SMS in the Haiti Earthquake. WWW 2012 - SWDM'12 Workshop, April 16-20, 2012, Lyon, France

[5] Hashimoto Yasuaki, Ohama Akihiro. 2014. The Role of Social Media in Emergency Response: The Case of the Great East Japan Earthquake. National Institute for Defense Studies, Journal of Defense and Security, Tokyo, Japan

\section{Kratka biografija:}

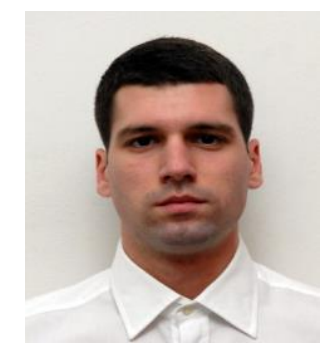

Nikola Resimić rođen je u Čačku 1989. godine. Osnovne akademske studije na Fakultetu bezbednosti u Beogradu iz oblasti Studije nauka bezbednosti završio je 2013. godine. Trenutno je student master studija na studijskom programu Upravljanje rizikom od katastrofalnih događaja i požara. 